\title{
Translating Gender in the 1980s: A New Historicist Perspective to Translations of Gladys Yang's Love Must Not Be Forgotten
}

\author{
Jiapei $\mathrm{Gu}^{1}$ \\ ${ }^{1}$ Department of Linguistics and Translation, City University of Hong Kong, Hong Kong, China \\ Correspondence: Jiapei Gu, Department of Linguistics and Translation, City University of Hong Kong, Hong \\ Kong, China. E-mail: jiapeigu3-c@my.cityu.edu.hk
}

Received: May 7, 2020 Accepted: June 9, 2020 Online Published: June 23, 2020

doi:10.5539/ells.v10n3p8 URL: https://doi.org/10.5539/ells.v10n3p8

\begin{abstract}
The article investigates the translation of Love Must not be Forgotten by British translator Gladys Yang from the perspective of New Historicism, focusing especially on the gender issues in the translation. The research first introduces New Historicism and explores the possibility of combining New Historicism and translation studies together. Then, case studies are conducted. The analysis of the translation, along with the analysis of many other texts, both literary and non-literary, such as newspaper or journal articles, considers three aspects. These are, namely: the translator's manipulation of the text; the ideas that the translator holds, and how all those texts, or discourses, create the positive representation of China in terms of gender issues in the 1980s. The paper, by using a Foucauldian approach, links translation, gender, and New Historicism together and thus successfully creates an interdisciplinary zone of enquiry. Overall, it can serve as a good example of how New Historicism and translation studies can be combined.
\end{abstract}

Keywords: gender issues, Gladys Yang, New Historicism, translation studies

\section{Introduction}

The paper, taking New Historicism as theoretical background, analyzes the feminist translation by a British literary translator, Gladys Yang, of a short story written by a well-known female Chinese writer Zhang Jie. The first part of this paper discusses the literary theory "New Historicism" by comparing it to traditional historicism and by explaining three key elements - textuality, non-literary texts, and power relations - in New Historicism. Then, why translation can be possibly studied from the perspective of New Historicism is explained with two reasons given. The second part introduces the translator and the source texts in order to give the readers some basic knowledge of the translation, the translator, and the source text. Then, the translation is analyzed to reveal the way the source text is understood and interpreted and the ideas that the interpreter holds as well. In addition, the paper uncovers the social backgrounds of both the source text and the target text by delving into many non-literary texts and also studies how all those texts together shape China into a positive image in terms of the gender issues. Overall, the analysis of the text from the New Historicism perspective answers following two issues of how the source text has been interpreted and how this translation helps us understand the gender issues in China at that time?

\section{Theoretical Background-New Historicism}

The term New Historicism, coined by Stephen Greenblatt, an American Shakespearean, literary historian, and author, is a form of literary theory, the goal of which is to understand history through both literature and non-literary text. There are three key elements of New Historicism that need to be emphasized, they are, textuality, non-literary text and power relations.

To begin with, new historians claim that the literature is textual. As Greenblatt (1980, p. 5) states, "both the social presence to the world of the literary text and the social presence of the world in the literary text". To put it simply, text itself is history. Unlike traditional historians, who reckon that the reality of history is more important than the literary text, the new historians emphasize that the text is the condensed history, from which one can gain access to the past. As Judith Newton $(1988$, p. 89) points out that "There is the notion that history is best told as a story of power relations and struggle, a story that is contradictory, heterogeneous, and fragmented". Thus, the literary text presents history and by studying the texts, the history of a specific period, the 
representation of a country or a person, the power relations, and so on, will be either thoroughly or shallowly unveiled. To quote Scheiding (2012), New Historicism dissolves the distinctions between literature and social life, and, in doing so, heralds the notion of culture as text.

Next, New Historicism is marked by its emphasis on non-literary texts. Non-literary texts, unlike literary texts, are texts like textbooks, articles, instruction manuals, legal documents, whose main purpose is to convey information without fictional elements. As Harrison observes (1991), the new historicist is not limited to the analysis of literary texts. This is because New Historicism is inter-textual, in other words, all texts combine to create the history. In order to thoroughly study history, or to interpret a text, a new historian needs to cross the boundaries of disciplines, for the research questions of this literary theory often have something to do with other disciplines, such as, politics, anthropology, sociology. The non-literary texts such as news, scripts, therefore, can be of great help in analyzing how the story is constructed, how it should be interpreted and how the work shapes reality. Also, they help literature critics to know more about the authors and social conditions at a particular period of time, and to better understand correlations among a collection of events, works, rules at a certain historically moment. The non-literary texts are valued as much as the literary texts in the New Historicism, which makes the New Historicism "impetuously rush beyond the confines of the canonical garden." (Greenblatt, 2000, p. 14)

The last point has to do with the power relation, a key concept in post-structuralism. Much of New Historicism is empowered by the concept of "power relations", or "knowledge and power" raised by Michel Foucault. According to Foucault (1982), power is "a way of acting upon an acting subject or acting subjects by virtue of their acting or being capable of action." In other words, power is not always referring to as physical power. Instead, it can also mean the metaphysical force that allows you to do or stops you from doing something. However, we are not always obedient to the power. Sometimes we contain it while sometimes we subvert it. As Leinwind (1990) argued, "Mediation, change, anti-authoritarianism - these are possible because power is mobile, vulnerable, and incomplete." When it comes to the New Historicism, it argues that discourses may challenge or subvert power. Therefore, a new historian, when analyzing a text, should attentively identify the power dynamics within the text, such as asking questions like who asks the writer to write this story? Why is "chairman" written as "chairperson" here? or, does it change reader's mind? Just as Stephen Greenblatt (1994) discovers, power produces its own subversion as the very "condition of power". That is, the writer may subvert the assumptions of a certain society at a specific time and then the novel may wield power over its readers, which encourages the readers to subvert the power in their life.

The new historicist approach becomes a useful historicist methodology for many fields, for instance, post-colonialism and gender studies, because of its revelation of power relation within or outside text and its application of non-literary texts. Using a new historicist approach to study literature, one can effectively expand his or her fields of study instead of solely focusing on the story itself. To name but a few, which phases of women's (Note 1) writing was the writer in; how patriarchy is manifested in the story; was the writer trying to subvert some assumptions and how. Reciprocally, feminism also boosts the development of New Historicism. To quote Greenblatt (2000, p. 11), "Women's studies, and the feminism that motivated its formation, has served as an important, if little acknowledged, model for New Historicism in that it has inspired its adherents to identify new objects for study, bring those objects into the light of critical attention, and insist upon their legitimate place in the curriculum." Therefore, women studies also help New Historicism to explore gender issues and thus brings new ideas and objects. The visibility of gender studies will constitute a new argument for defining New Historicism in a broader way.

This paper, taking New Historicism as theoretical background, chooses a feminist translation of a literary text Love Must not be Forgotten to analyze. Translation is rarely studied from the perspective of New Historicism. The combination of translation studies and New Historicism, however, is a fertile ground for the researchers. There are two reasons why combining translation studies and New Historicism is possible. Firstly, the translation is a writer's interpretation of the text. Translating is a process whereby the translator reads the text, interprets it in his or her mind and rewrites it in his or her own language. And during the process of interpreting the text, the translator must refer to many other texts, both literary and non-literary, say, dictionaries and local chronicles, so as to, in the most cases, assure that the translation will not deviate too much from the source texts. In addition, the way a translator rewrites the story also reveals how he or she views the story. When studying the translation, or, to put it straightforwardly, the translator's interpretation of the source, we are actually studying the two questions in New Historicism raised by Tyson (2006, p. 287) - "how has the event been interpreted" and "what do the interpretations tells about the interpreters". So, in this case, studying translation, namely, how the text is translated and what does translation tell us about the translator, is in fact a new historicist way of studying a text. 
Secondly, both New Historicism and translation studies consider how authors and translators shape their texts. New Historicism aims to study the writer's manipulation of text and to dig out the hidden intentions of whether catering to or subverting certain ideologies; similarly, translation "is a textual and discursive practice that is under the impact of the ideological and historical context in which it emerges." (Khadem-Nabi \& Gharesoufloo, 2014) Thus, part of translation studies tries to uncover the aim of each manipulations, and the aims of which, identically, could be catering to or subverting certain ideologies. For instance, the paragraph is deliberately deleted in translation because it is against the ideology of the target language world. The role of women is highlighted in translation due to the fact that the translator is a hardcore feminist. Translation studies, however, tend to focus on the translation, while the new historicist approach looks at many other aspects, such as what else is translated in that period and how they work together to create discourse. Therefore, New Historicism can expand translation studies into the larger areas. So, if we think in this way: translation, being a type of text, also constitutes and shapes history, then, New Historicism can possibly be a good tool for studying translation. In other words, this paper could be a good try by answering two aforementioned questions.

\section{Material Studied}

This short romantic story was written by Zhang Jie, a popular female Chinese writer. It tells the story of a mother who had devoted the best part of her life to a man she rarely saw, a man who had married the daughter of a worker, who was his life-saver, out of allegiance to the morality, responsibility and the ideal of a classless society. The main character Shanshan, the daughter of that mother, accidentally discovers her dead mother's diaries and realizes that for all these years, her mother was deeply in love with that man until her death. In the end, inspired by her mother's unfilled, silent, but everlasting love, she rejected her handsome suitor, for whom she had no feeling. The story delivers a message that it is better not to marry someone you do not love, neither under the pressure of peers, family nor society.

\section{Analysis of the Translation}

\subsection{What Does the Translation Help Us Understand the Gender Issues in China at that Time?}

The time in which the source text was translated was at the peak of the second wave of feminism. In the early period of the second wave, a French female writer Simone de Beauvoir published her groundbreaking book, The Second Sex (1972), in which she raised a fundamental concept, that is, "one is not born, but rather becomes a woman". She believes that women are socially and discursively constructed rather than born to be ignorant or obedient. Then, on May 9, 1960, The Food and Drug Administration (FDA) approves the world's commercially produced oral contraceptive pill, which granted greater reproductive freedom to women.

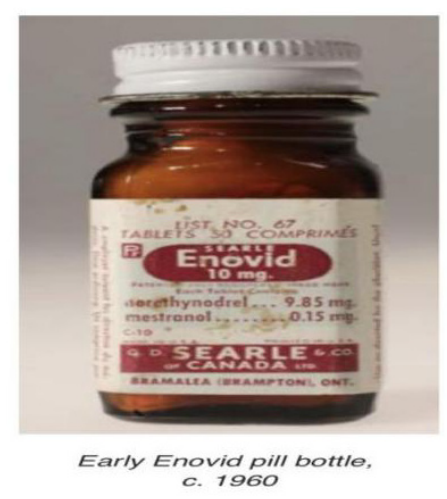

Figure 1. Oral contraceptive pill

The two events mentioned above reveal the fact that gender issues were increasingly drawing public attentions in the western world. But how did the westerner view gender issues in China and how were the gender issues in China? There is a paragraph, which was written by an American student, in the collection China!: Inside the People's Republic (1972) that describes women in China,

"Travelling through China we saw old women with feet painfully crippled from foot-binding, younger women working in the fields and operating machinery in factories, and younger women working in the fields and operating machinery in factories, and middle-school girls shooting rifles in a militia drill. These 
contrasts convinced us that the changes in the lives of women since liberation may be one of the greatest miracles of the Chinese Revolutions." (p. 266)

This paragraph admires the Chinese Revolutions as "the greatest miracles", which liberate Chinese women from the house trivia. And from the paragraph we can see that Chinese women were "working in the field and operating machinery in factories", and they could even practice shooting as men do. Chinese women engaging in works that are originally taken by men shows that China in the 1980s, in which women were no longer being considered as weak strength, provided equal job opportunities to both men and women. Also, in Feminism and Socialism in China, Croll (1978, p. 2) points out that "no longer did they think of themselves 'as different from men as earth was from heaven', but as half of China holding up or constituting the other 'half of heaven'". Once again, the Chinese women are portraited as strong, independent figures that could make equal contribution to the country. In addition, during the speech by Eileen Klehr, Member of the Central Committee on International Women's Day 1972 at Los Angeles, she highly praised the effort that China has made on gender equality in the workplace and pointed out that "Chinese women have begun to be freed from the age-old ties to household labor and the nursery of which we spoke earlier". Hence, we can safely conclude that in the 1980s, at the time when China was recovering from the Cultural Revolution, China was depicted as a democratic country that was striving for gender equality, at least, in the workplace.

The translation also helps to build up the image of Chinese women gaining gender equality by rewriting some sentences and words. The concept of rewriting is developed by Lefevre. He views translation as a form of rewriting, which means that texts are produced from one to another in order to adapt certain ideologies or poetics. Here the translation, firstly, by translating “校长” (the principal), a position that is usually taken by men, into "headmistress", depicts China as a place where men and women have equal access to the high position. Furthermore, by rewriting the sentence “我不過是一頭劣種的牲畜, 卻變著法兒想要混個肯出大價錢的冤大 頭”(in their imagination, I am only an inferior, low-qualified animal, who is trying to find a stupid man who is willing to buy me in a high price), the translator downplays the negative image of Chinese women constantly being objectified as commodities. Also, in the translation, the girls have great say on their choice on marriage, as they are "contemplating" the marriage instead of "being ready for the marriage". In addition, the translation directly subverts the assumption in the source text - women should sometimes be coy, so as to tell the readers that the Chinese women have already became self-conscious, since they do not want to pretend to be coy. There are, of course, some other rewritings that the translator made in order to create positive image of gender equality in China. Together with other works, the translation undoubtedly will further promote the image of China in terms of the gender equality in the western world.

\subsection{How Has the Source Text Been Interpreted?}

Source text: 淒悽惶惶地站在那嚴厲的校長面前一樣。

Target text: standing forlornly in front of the stern headmistress.

In the original text, “校长”(the principal) does not specifically refer to someone. It is mentioned to show how embarrassed the mother is, as if she is scolded by a principal. The possible translations of the word "校长”"(the principal) could be, as mentioned, principal, or headmaster, headmistress. But it is hard to tell whether the principal mentioned here is male or female. Nevertheless, from the translator's choice of "headmistress", we can learn that she was trying to fight against the patriarchal idea of men owns better jobs. As argued by Marcin Lewandowski (2014), "men are more frequently shown in professional settings than women. Most of the aforementioned studies have also found that males are stereotyped as working in a broader range of occupations, and are more likely to hold prestigious jobs and positions." Perhaps, the translator, being a female, has noticed such unfair phenomenon in the society and thereby wanted to change the status quo of gender inequality in workplace through her works by appointing the promising job to the female character. Of course, to shake off the stereotype in the workplace is no easy task, but here the translator shows her stance and makes effort to promote the female image in the workplace by making slight manipulation of her translation.

Source text: 好像我不是一個準備出嫁的姑娘。

Target text: Instead of being a girl contemplating marriage.

When we look into the target, we may find that the target is not entirely a literal translation, as it were, of the source. The literal translation of the source would be "instead of being a girl ready to marry someone". At the first glance, "contemplating marriage" and "ready to marry someone" do not differ greatly in terms of meaning. But if we give it a second thought, those two clauses actually contain very different meanings. The word "contemplation", according to the Dictionary, means "think deeply and at length". So, different from "ready", 
which implies that girl has made her decision of stepping into marriage, the word "contemplating" shows that the girl is still considering whether to marry herself off or not. The decision has not been made. She may say yes if she finds marriage is suitable for her; or not, if marriage does her no good. In the translation, the words "contemplating" strengthens the subversive notion raised in the source text of women should marry voluntarily to the one she really loves, instead of randomly rushing into marriage as if it is a natural thing to do".

Source text: 大約在一九六二年的春天, 我和母親去聽音樂會。

Target text: In the spring of 1962, Mother took me to a concert.

The word "Mother" first appears in the above sentence. It is eye-catching because the letter " $\mathrm{M}$ ", in accordance with the grammar rule, should not be capitalized since it is not the letter at the beginning of a sentence. The English readers may easily consider it as an inattentive typo here. However, if we continue reading, we will find that all letters of $\mathrm{m}$ in "mother" are capitalized, say, "with Mother", "I glanced at Mother's face", and so on. Then, this is unlikely a typo here, unless the translator and the editor were really paying no attention to their work. But what could be the intention of capitalizing M? One possible explanation, the writer of this paper believes, is that the translator was making effort to differentiate the mother in the story from the mother in the traditional sense. Traditionally, a mother should be the wife of a man, the caregiver of a family, and is supposed to be dependent on the male members of the family, be trapped by the household chores, and be considered as "others". The mother in the story, however, is different from that of the traditional. She is undoubtedly independent, who has her own job as writer and raises up her daughter on her own. And spiritually, she is avant-garde. She encourages her daughter to stay unmarried if she cannot find her true love. This mother bravely subverts the tradition notion of women should marry to someone, ideally, rich and good-looking in the early age. And the translator senses the subversion in the original, also makes her effort to support this by capitalizing the letter " $m$ ", and thus highlighting and advocating the subversion jointly with the original writer.

Source text: 在他們的想像中, 我不過是一頭劣種的牲畜, 卻變著法兒想要混個肯出大價錢的冤大頭。

Target text: To them, I'm a nobody playing hard to get.

Here the translator adopts the strategy of free translation. The literal translation of the source would be "in their imagination, I am only an inferior, low-qualified animal, who is trying to find a stupid man who is willing to buy me in a high price." The source text objectifies women as commodities purchasable by men, and satires how the main character Shanshan plays tricks to raise her "price". Here I need to point out that the author by no means agrees with this discriminatory thinking. But instead, she is trying to be ironic. This sentence reveals that the women in that period of time view marriage as a trade. Also, from their devaluation of other women, who are not married in the "proper" age, we see no woman solidarity among them. The target text, on the contrary, rewrites the sentence into a less offensive one. Instead of degrading the women into commodities, the translator deletes the insulting expressions and interprets it as "a nobody playing hard to get". By doing so, the translator weakens the inferiority of women in the text.

Source text: 我不知道一個姑娘什麼時候需要做出害臊或忸怩的姿態。

Target text: I can't think why a girl should pretend to be coy.

The literal translation would be rendered as "when a girl should pretend to be coy". The assumption behind the source text is that a girl should be coy in the right occasion from time to time. And the question that the author drops here is when it can be considered as "the right occasion". But, the interpreter does not quite agree with this point. Conversely, she changes the word "when" into "why" and thus fundamentally alters the assumption here. "why should a girl pretend to be coy?" the hidden assumption could be that the girl does not need to pretend to be coy at all. Why would a girl pretend to be coy? To ask for help? To attract men? To show weakness? It is the society that constantly tells us that girls should be coy because it is cute. As a result, the women, being socially constructed, naturally pretend to be coy when it is needed, which, ironically, is by no means natural. So, being fully aware of this, the interpreter, by substituting the word "when" to "why", powerfully casts doubt on the old assumption of "women should pretend to be coy" and replace it with her own assumption - women should not pretend to be coy when they are actually not.

\section{Conclusion}

This paper, taking Love Must not be Forgotten as a case, attempts to combine translation studies and New Historicism together. In the paper, the three key elements of New Historicism are discussed. And the paper also explores how translation can be studies from new historicist perspective. That is, New Historicism, by introducing many non-literary texts and other contexts, expands translation studies into broader areas. Then, the analysis of translation from the perspective of New Historicism is done by answering two questions. In the 
process, we learn that the translator has conducted some rewritings - capitalizing the letter M, adopting free translation, changing some key words - on the texts, so as to either contain or subvert the ideas raised in the original. Also, by studying the non-literary texts produced around 1980s on the gender issues in China and the manipulations in the translation, we are able to know more about how the positive representation of China in terms of gender issues was constructed. In conclusion, this is a good try on the combination of translation studies and New Historicism. Being an interdisciplinary paper linking translation, gender and New Historicism, it will provide a guidance for the future relevant studies on how translation, together with other texts, both literary and non-literary, reveals or reconstructs history.

\section{Acknowledgement}

I sincerely thank Dr. Dominic Glynn for revising and proofreading my article, and for providing valuable suggestions on the improvement of the article.

\section{References}

Beauvoir, S., \& Parshley, H. (1972). The second sex. Harmondsworth: Penguin.

Committee of Concerned Asian Scholars. (1972). China!: Inside the People's Republic. New York: Bantam Books.

Contemplation. (n.d.). Retrieved April 30, 2020, from https://www.lexico.com/definition/contemplate

Croll, E. (1978). Feminism and Socialism in China (Routledge Revivals). Routledge.

Foucault, M. (1980). The history of sexuality. New York: Vintage Books. https://doi.org/10.3366/olr.1980.002

Foucault, M. (1982). The Subject and Power. Critical Inquiry, 8(4), 777-795. https://doi.org/10.1086/448181

Gallagher, C., \& Greenblatt, S. (2000). Practicing New Historicism. Chicago: University of Chicago Press.

Greenblatt, S. (1980). Renaissance Self-Fashioning: From More to Shakespeare. Chicago: The University of Chicago Press.

Greenblatt, S. (1994). Invisible Bullets: Renaissance authority and its subversion, Henry IV and Henry V. In Political Shakespeare: essays in cultural materialism (pp. 19-47). Manchester: Manchester University Press.

Harrison, A. (1991). Matthew Arnold's Gipsies: Intertextuality and the New Historicism. Victorian Poetry, 29(4), 365-383. Retrieved April 28, 2020, from www.jstor.org/stable/40003003

Hua, M., \& Li, C. F. (2014). The Translator's Visibility of Gladys Yang's Independent Translation from the Perspective of Translators-Taking the English Version of Love Must Not Be Forgotten as a Case. Journal of Jiangxi Normal University, 47(04), 134-140.

Leinwand, T. B. (1990). Negotiation and New Historicism (in English Renaissance drama). PMLA, 105(3), 477-490. https://doi.org/10.2307/462896

Lewandowski, M. (2014). Gender stereotyping in EFL grammar textbooks. A diachronic approach. Linguistik Online, 68(6), 83-99.

Mir M. K.-N., \& Elaheh, G. (2014). New Historicism in Translation Studies. International Journal of Applied Linguistics and English Literature, 3(6), 29-34. https://doi.org/10.7575/aiac.ijalel.v.3n.6p.29

Newton, J. (1988). History as Usual?: Feminism and the "New Historicism". Cultural Critique, 9, 87-121. https://doi.org/10.2307/1354235

Scheiding, O. (2012). New Historicism and Discourse Analysis. In M. Middeke, T. Müller, C. Wald \& H. Zapf (Eds.), English and American Studies. J.B. Metzler, Stuttgart.

Showalter, E. (1977). A literature of their own: British women novelists from Brontë to Lessing. Princeton, N.J.: Princeton University Press.

Tyson, L., \& Ebrary, Inc. (2006). Critical theory today: A user-friendly guide (2nd ed.). New York: Routledge.

Zhang, J. (1980). Love Must Not Be Forgotten (1st ed.). Guangzhou: Guangdong People's Publishing House.

Zhang, J., \& Yang, G. (1987). Love must not be forgotten. Beijing: San Francisco: Panda; China Books \& Periodicals. 


\section{Note}

Note 1. In Showalter's A Literature of Their Own (1977), she proposes three phases of women's writing Feminine phase, Feminist phase and Female phase.

\section{Copyrights}

Copyright for this article is retained by the author, with first publication rights granted to the journal.

This is an open-access article distributed under the terms and conditions of the Creative Commons Attribution license (http://creativecommons.org/licenses/by/4.0/). 